\title{
Penentuan Derajat Luka pada Kekerasan Mekanik di RSUP Prof. Dr. R. D. Kandou Manado Periode Januari - Juli 2019
}

\author{
Jessica E. Kelwulan, ${ }^{1}$ James F. Siwu, ${ }^{2}$ Johannis F. Mallo
}

\author{
${ }^{1}$ Progam Studi Pendidikan Dokter Fakultas Kedokteran Universitas Sam Ratulangi Manado \\ ${ }^{2}$ Bagian Ilmu Kedokteran Forensik dan Medikolegal Fakultas Kedokteran Universitas Sam \\ Ratulangi/RSUP Prof. Dr. R. D. Kandou \\ Email: jessica.kelwulan@yahoo.com
}

\begin{abstract}
Determination of the degree of injury is highly important to identify the type and severity of abuse, in order to decide the level of punishment against the perpetrators. In case of living victim, a doctor may provide information regarding the injury. Type of injury, type of violence that caused the injury, and determination of injury's qualification or degree of injury, will be translated in the form of Visum et Repertum . Visum et Repertum is necessary to uncover clarity, truth and complete proof of material about a crime. It is important for a doctor to be able to determine the qualification of an injury in order to decide the severity of the sentence against the suspect. This study was aimed to determine the degree of injury in mechanical violence at Prof. Dr. R. D. Kandou Hospital Manado from January to July 2019. This was a retrospective and descriptive study using Visum et Repertum data. The results obtained 39 cases of mechanical violence. Majority of cases had sharp violence ( 24 cases; $61.5 \%$ ), second degree injuries ( 29 cases; $74.4 \%$ ), males (34 cases; 87\%), and the age range was 15-24 years old (17 cases; $43.5 \%$ ). In conclusion, most cases were males, age range of 15-24 years, had sharp violence with second degree injury.
\end{abstract}

Keywords: mechanical violence, degree of injury

\begin{abstract}
Abstrak: Penentuan derajat luka sangat penting dilakukan untuk mengetahui jenis penganiayaan yang dilakukan dan berat ringannya ancaman hukuman terhadap pelaku. Visum et Repertum (VeR) sangat diperlukan untuk mencari kejelasan, kebenaran, dan pembuktian materil yang selengkap-lengkapnya tentang suatu tindak pidana. Kemampuan seorang dokter dalam menentukan kualifikasi luka sangat penting bagi pihak berwajib untuk menentukan berat ringannya hukuman terhadap tersangka. Penelitian ini bertujuan untuk mengetahui derajat luka pada kekerasan mekanik di RSUP Prof. Dr. R. D. Kandou Manado periode Januari sampai Juli 2019. Jenis penelitian ialah deskriptif retrospektif dengan menggunakan data hasil VeR. Hasil penelitian mendapatkan sebanyak 39 kasus kekerasan mekanik. Mayoritas kasus ialah akibat kekerasan tajam pada 24 kasus $(61,5 \%)$, luka derajat dua pada 29 kasus $(74,4 \%)$, jenis kelamin laki-laki pada 34 kasus (87\%), dan rentang usia 15-24 tahun pada 17 kasus (43,5\%). Simpulan penelitian ini ialah sebagian besar kasus berjenis kelamin laki-laki, rentang usia 15-24 tahun, dengan kekerasan tajam dan luka derajat dua.
\end{abstract}

Kata kunci: kekerasan mekanik, derajat luka

\section{PENDAHULUAN}

Penentuan derajat luka sangat penting dilakukan untuk mengetahui jenis penganiayaan yang dilakukan dan berat ringannya ancaman hukuman terhadap pelaku. ${ }^{1}$ Seorang dokter dalam praktik sehari-hari, tidak hanya ditugaskan melakukan pemeriksaan untuk kepentingan diagnostik dan pengobatan suatu penyakit saja, tetapi juga untuk membuat suatu keterangan medis. Hal ini terkait pada pasien yang dicurigai merupakan korban suatu tindak pidana, atas dasar 
surat permintaan keterangan medis dari pihak yang penyidik. ${ }^{2}$ Sesuai dengan profesinya, seorang dokter mempunyai kewajiban membantu penegak hukum untuk membuktikan korban merupakan kasus tindak pidana atau bukan, dengan cara melakukan pemeriksaan pada korban dan melaporkannya dalam bentuk surat yang disebut Visum et Repertum (VeR). ${ }^{3}$

Visum et Repertum adalah suatu surat keterangan tertulis yang dibuat oleh seorang dokter sesuai dengan permintaan resmi dari penyidik yang memuat hasil suatu pemeriksaan medis terhadap tubuh seorang manusia baik hidup atau mati, yang berlandaskan sumpah pada saat menerima jabatan dan demi kepentingan peradilan. $^{2}$ Visum et Repertum merupakan salah satu alat bukti yang sah sebagaimana tertulis dalam pasal 184 KUHAP. Maka dari itu pada waktu memberi laporan pemberitaan dari VeR itu harus yang sesungguh-sungguhnya dan seobyektif mungkin tentang apa yang dilihat dan ditemukan pada waktu pemeriksaan. ${ }^{2}$

Pada kasus perlukaan korban hidup, seorang dokter diharapkan dapat memberikan informasi mengenai identitas korban, jenis luka, jenis kekerasan yang menyebabkan luka, dan menentukan derajat luka atau kualifikasi luka yang nantinya akan ditulis dalam bentuk VeR, sehingga dapat digunakan sebagai alat bukti yang bisa meyakinkan hakim untuk memutuskan suatu tindak pidana. ${ }^{1,4,5}$

Penentuan derajat luka atau kualifikasi luka dapat dilihat pada bagian kesimpulan VeR yang ditulis dokter menurut rumusan pasal 351, 352, dan 90 Kitab UndangUndang Hukum Pidana (KUHP) . Rumusan ketiga pasal tersebut secara implisit membedakan derajat perlukaan yang dialami korban menjadi luka ringan, luka sedang, dan luka berat. Secara hukum, ketiga keadaan luka tersebut menimbulkan konsekuensi pemidanaan yang berbeda bagi pelakunya. ${ }^{4}$ Meskipun pada simpulan VeR tidak menyebutkan derajat luka secara eksplisit, namun rumusan simpulan tetap menunjukkan derajat lukanya. Derajat luka ringan biasanya dituliskan sebagai "luka yang tidak menimbulkan penyakit atau halangan dalam mela- kukan pekerjaan, jabatan atau pencahariannya", sedangkan derajat luka sedang biasanya dituliskan "yang menimbulkan penyakit yang mengakibatkan halangan dalam melakukan pekerjaan, jabatan atau pencahariannya untuk sementara waktu ...", dan derajat luka berat "yang menimbulkan penyakit yang mengakibatkan halangan dalam melakukan pekerjaan, jabatan atau pencahariannya, dan menimbulkan luka berat sebagaimana yang sudah diatur dalam pasal 90 KUHP". 5

Pada umumnya penentuan derajat luka tidaklah sulit bagi seorang dokter akan tetapi sampai saat ini belum ada standarisasi dari penen-tuan derajat luka. Meskipun di dalam praktik di Indonesia telah digunakan patokan dalam menentukan derajat luka, namun pada penentuan derajat luka pada kasuskasus tertentu dapat terjadi perbedaan pendapat di antara para dokter. Hal ini tidak menjadi masalah sepanjang apa yang dibuat oleh dokter bisa dipertanggung-jawabkan secara ilmiah. ${ }^{1,5}$ Kesalahan dalam penentuan derajat luka dapat menimbulkan ketidakadilan bagi korban maupun pelaku tindak pidana. Ketidak tepatan penentuan derajat luka akan berdampak pada ketentuan pidana yang akan diterapkan pada kasus, yang kemudian akan memengaruhi besarnya ancaman pidana yang akan dikenakan terhadap pelaku.

Hukum Pidana Indonesia mengenal delik penganiayaan yang terdiri dari tiga tingkatan dengan hukuman yang berbeda, yaitu penganiayaan ringan (pidana maksimum 3 bulan penjara) yang diatur dalam pasal 352 (1) KUHP; penganiayaan (pidana maksimum 2 tahun 8 bulan) yang diatur dalam pasal 351 (1) KUHP; dan penganiayaan yang menimbulkan luka berat (pidana maksimum 5 tahun) diatur dalam pasal 352 (2) KUHP. Yang dimaksud luka berat dalam pasal 352 (2) KUHP yaitu jika pada saat dilakukan pemeriksaan dan didapati salah satu luka sebagaimana dicantumkan dalam pasal 90 KUHP maka korban tersebut dimasukkan dalam penganiayaan berat. Setiap kecederaan harus dikaitkan dengan ketiga pasal tersebut. ${ }^{4,5}$

Untuk itulah kemampuan seorang 
dokter dalam menentukan kualifikasi luka sangat penting bagi pihak berwajib untuk menentukan berat ringannya hukuman terhadap tersangka. Karena berat ringannya hukuman terhadap tersangka dilihat dari berat ringannya luka pada korban kekerasan yang tertuang dalam derajat atau kualifikasi luka yang dibuat oleh dokter.

Berdasarkan uraian di atas penulis tertarik untuk meneliti tentang derajat luka, karena derajat luka yang dibuat dokter akan menentukan tuntutan hukuman seseorang.

\section{METODE PENELITIAN}

Jenis penelitian ini ialah deskriptif retrospektif dengan menggunakan data sekunder yang diambil di RSUP Prof. Dr. R. D. Kandou Manado. Subjek penelitian ialah seluruh data kasus kekerasan mekanik dalam surat keterangan VeR yang ada di RSUP Prof. Dr. R. D. Kandou Manado dan diambil data mengenai derajat luka pada kekerasan mekanik selama periode Januari Juli 2019. Variabel penelitian ini ialah jumlah kasus kekerasan mekanik, derajat luka, usia, dan jenis kelamin.

Penelitian ini telah mendapat persetujuan dari Komisi Etik Penelitian Kesehatan RSUP Prof. Dr. R. D. Kandou Manado, dengan nomor keterangan layak etik yaitu No. 074/EC/KEPK-KANDOU/XI/2019

\section{HASIL PENELITIAN}

Berdasarkan data dari hasil VeR yang diambil di RSUP Prof. Dr. R. D. Kandou Manado selama periode Januari - Juli 2019, didapatkan sebanyak 39 kasus kekerasan mekanik yang terdiri dari kekerasan tajam sebanyak 24 kasus dan kekerasan tumpul 15 kasus. Tidak ditemukan kasus kekerasan akibat senjata api selama periode tersebut. Berdasarkan data jenis kelamin didapatkan sebanyak 34 kasus kekerasan yang terjadi pada laki-laki dan hanya 5 kasus kekerasan yang terjadi pada perempuan.

Tabel 1 memperlihatkan distribusi usia dari kasus kekerasan mekanik. Usia terbanyak berada pada rentang usia 15-24 tahun dengan jumlah 17 kasus.

Tabel 2 memperlihatkan distribusi derajat luka berdasarkan kasus kekerasan mekanik. Dari keseluruhan kasus kekerasan yang paling banyak ditemukan ialah derajat luka dua dengan jumlah 29 kasus.

Tabel 1. Jumlah kasus berdasarkan usia

\begin{tabular}{ccc}
\hline $\begin{array}{c}\text { Usia } \\
\text { (tahun) }\end{array}$ & Jumlah & $\begin{array}{c}\text { Persentase } \\
(\%)\end{array}$ \\
\hline$<5$ & 0 & 0 \\
$5-14$ & 0 & 0 \\
$15-24$ & 17 & 43,5 \\
$25-44$ & 14 & 35,8 \\
$45-64$ & 8 & 20,5 \\
$>65$ & 0 & 0 \\
Total & 39 & 100 \\
\hline
\end{tabular}

Tabel 2. Jumlah kasus kekerasan mekanik berdasarkan derajat luka

\begin{tabular}{ccc}
\hline Derajat luka & Jumlah & $\begin{array}{c}\text { Persentase } \\
(\boldsymbol{\%})\end{array}$ \\
\hline I & 6 & 15,4 \\
II & 29 & 74,4 \\
III & 4 & 10,3 \\
Total & 39 & 100 \\
\hline
\end{tabular}

\section{BAHASAN}

Hasil penelitian ini mendapatkan sebanyak 39 kasus kekerasan mekanik yang dimintakan VeR di RSUP Prof. Dr. R. D. Kandou Manado selama periode Januari Juli 2019. Kekerasan mekanik terdiri dari kekerasan tajam, kekerasan tumpul, dan senjata api. Dari keseluruhan kasus yang paling banyak terjadi ialah kekerasan tajam dengan jumlah 24 kasus $(61,5 \%)$, kekerasan tumpul 15 kasus $(38,5 \%)$; tidak ada kasus kekerasan senjata api (0\%). Hasil ini sesuai dengan penelitian yang dilakukan di RSUD Dr. R. M. Pratomo Bagansiapiapi yang mendapatkan paling banyak kekerasan tajam dengan jumlah kasus sebanyak 28 kasus $(58,3 \%){ }^{6}$

Luka akibat benda tajam dapat berupa luka iris atau luka sayat, luka tusuk, dan luka bacok. Luka tersebut didapatkan dari benda bersifat tajam seperti pisau, golok, dan sebagainya. ${ }^{2}$ Alat-alat tersebut sering dijumpai di kehidupan sehari-hari; hal inilah yang memungkinkan kekerasan tajam lebih sering terjadi dibandingkan dengan kekerasan tumpul atau senjata api. Penulisan jenis kekerasan dalam VeR dapat memper- 
kuat bukti dalam persidangan yang menandakan bahwa korban telah mengalami peristiwa kekerasan sehingga dapat dijadikan pertimbangan bagi hakim dalam menjatuhkan pidana. ${ }^{7}$

Kasus kekerasan mekanik berdasarkan jenis kelamin yaitu sebanyak 34 orang lakilaki dan 5 orang perempuan. Dari keseluruhan kasus yang didapatkan kebanyakan kasus terjadi pada laki-laki. Hal ini mungkin disebabkan oleh beberapa faktor. Secara teori laki-laki memiliki sex determining region $\mathrm{Y}$ (SRY), yang dapat memengaruhi tingkat agresivitasnya dalam merespon terhadap suatu hal. Laki-laki memiliki tingkat agresivitas yang jauh lebih tinggi dibandingkan perempuan. ${ }^{8}$ Sifat agresif yang dimiliki laki-laki selalu lebih berkompetitif dibandingkan perempuan; hal ini menyebabkan laki-laki lebih sering melakukan kejahatan dan kemungkinan besar juga menjadi korban dari kejahatan tersebut. ${ }^{9}$

Berdasarkan usia didapatkan bahwa kasus kekerasan mekanik yang terjadi lebih banyak pada usia remaja sampai dewasa awal (15-24 tahun) yaitu sebanyak 17 kasus. Hasil penelitian Astuti ${ }^{10}$ menjelaskan bahwa usia produktif memiliki pengaruh terhadap tindakan kriminalitas yang dilakukan seseorang dan sebagian besar kejahatan tersebut dilakukan oleh orang-orang dengan usia relatif muda. Selain itu menurut Harlock, ${ }^{11}$ dewasa muda merupakan masa peralihan dari remaja menuju individu yang lebih dewasa yang mencari jati diri dan telah menyelesaikan masa pertumbuhannya serta siap menerima kedudukan dalam masyarakat bersama dengan individu dewasa lainnya. Dalam kondisi seperti ini, pengaruh lingkungan luar serta teman sebaya memiliki pengaruh besar terhadap emosional seseorang, sehingga tidak jarang terjadi kekerasan atau penganiayaan yang dilakukan oleh orang-orang pada masa dewasa awal. $^{12}$

Penentuan derajat luka dibuat untuk membantu pihak penegak hukum untuk memberikan dakwaan terhadap tersangka. Lewat VeR ini dapat diketahui pasal-pasal dan hukuman yang harus diberikan kepada tersangka. Data kekerasan mekanik berda- sarkan derajat luka yang diperoleh dari VeR pada bagian simpulan akan tertulis bahwa korban tersebut tergolong dalam luka derajat berapa. Hasil penelitian ini mendapatkan bahwa dari 39 kasus kekerasan yang terjadi, luka derajat dua $(74,4 \%)$ paling banyak didapatkan. Hal ini mungkin dikarenakan kekerasan yang terjadi pada pada korban tidak terkena pada bagian tubuh yang mematikan seperti daerah leher, dada, dan perut yang merupakan tempat organ vital.

Dari keseluruhan data yang diperoleh selama periode Januari sampai Juli 2019 tidak terdapat kasus yang masuk dengan luka tembak akibat senjata api. Hal ini mungkin disebabkan karena perdagangan senjata api di Indonesia tidak seluas dan semudah masyarakat di negara lain. Oleh karena itu, hanya orang-orang tertentu memiliki ijin dari pihak kepolisian untuk menggunakan senjata api. Selain itu, kekerasan akibat senjata api sangat mudah dikenali dan meninggalkan jejak peluru. Walaupun demikian, mungkin selama periode Januari sampai Juli 2019 terdapat kasus kekerasan akibat senjata api namun tidak dimintakan VeR ke RSUP Prof. Dr. R. D. Kandou Manado.

\section{SIMPULAN}

Selama periode Januari-Juli 2019 di RSUP Prof. Dr. R. D. Kandou Manado didapatkan 39 kasus akibat kekerasan mekanik. Jumlah kasus terbanyak ialah akibat kekerasan tajam, jenis kelamin laki-laki, masa remaja awal sampai dewasa akhir. dengan luka derajat dua.

Penelitian demikian perlu dilanjutkan tiap tahunnya untuk menilai angka kejadian serta trend kekerasan mekanik yang terjadi. Penelitian ini sebaiknya dilakukan dengan kerjasama pihak kepolisian dan keluarga untuk mendapatkan hasil yang lebih akurat.

\section{Konflik Kepentingan}

Penulis menyatakan tidak terdapat konflik kepentingan dalam studi ini.

\section{DAFTAR PUSTAKA}

1. Susanti R. Paradigma baru peran dokter dalam pelayanan kedokteran forensik. Majalah 
Kedokteran Andalas. 2012; 36(2):14554.

2. Budiyanto A, Widiatmaka W, Sudiono S, Mun'im TWA, Sidhi, Hartian S, et al. Ilmu Kedokteran Forensik. Jakarta: Bagian Kedokteran Forensik Fakultas Kedokteran Universitas Indonesia; 1997.

3. Syahrizal D, Senja N. Undang-undang Prak-tik Kedokteran \& Aplikasinya. Jakarta: Dunia Cerdas, 2013.

4. Afandi D. Visum et repertum perlukaan aspek medikolegal dan penentuan derajat luka. Majalah Kedokteran Indonesia. 2010; 60(4):188-95.

5. Fatriah SH, Sampurna B, Firmansyah A. Analisis medikolegal terhadap kriteria derajat luka menurut Kitab UndangUndang Hukum Pidana. J Indon Med Assoc. 2017;67(11):514-21.

6. Ramadhan FT, Afandi D, Mursali LB. Kualitas visum et repertum perlukaan di RSUD DR. R M. Pratomo Bagan Siapi-api periode 1 Januari 2009 - 31 Desember 2013. JOM FK 2015;2(1):
$1-13$.

7. Satyo AC. Aspek medikolegal luka pada forensik klinik. Majalah Kedokteran Indonesia. 2006;39(4):430-2.

8. Mirani E. Pengaruh konseling genetik pada tingkat kecemasan dan depresi terhadap penentuan gender ambigus genitalia [Tesis]. Semarang: Universitas Diponegoro; 2009.

9. Barash DP. Evolution, males, and violence. 2002. [cited 2019 Oct 28]. Available form: www.physics.ohio-state.edu/ $\sim$ wilkins/writing/Assign/so/maleviolence.html

10. Astuti NW. Analisis tingkat kriminalitas di Kota Semarang dengan pendekatan ekonomi tahun 2010-2012 [Skripsi]. Semarang: Fakultas Ekonomi dan Bisnis Universitas Diponegoro; 2014.

11. Hurlock E. Psiologi Perkembangan. Jakarta: PT Gramedia Pustaka, 2004.

12. Hardiyani T. Perbedaan pengendalian emosi marah antara laki-laki dan perempuan pada masa dewasa awal [Skripsi]. Malang: Universitas Brawijaya; 2014. 